Article

\title{
Combining Choice Analysis with Stakeholder Consultation to Assess Management Options for New Zealand's Hurunui River
}

\author{
Dan Marsh * and Yvonne Phillips \\ Department of Economics, University of Waikato, Hamilton 3105, New Zealand; \\ E-Mail: ysm1nz@gmail.com \\ * Author to whom correspondence should be addressed; E-Mail: dmarsh@waikato.ac.nz; \\ Tel.: +64-7-838-4950.
}

Academic Editor: Markus Disse

Received: 26 January 2015 / Accepted: 10 April 2015 / Published: 17 April 2015

\begin{abstract}
Choice experiments can be designed using information gathered in stakeholder consultation processes. Information from these two sources can be used to consider both consultation outcomes and population preferences in environmental decision making. This approach is demonstrated using a case study of New Zealand's Hurunui River which has been hotly contested between those who seek to divert water and increase agricultural production and those who would like to see the river undeveloped and the natural resources in the river and catchment improved. Data from the choice experiment is used to describe and quantify the preferences of Canterbury Region residents for existing conditions (good quality in the main river and poor quality in the tributaries) and potential future land use scenarios for the catchment. Six scenarios ranging from forestry to intensive irrigation could result in deterioration or improvement. Quantitative information from the choice experiment was provided to policy makers as they considered the outcomes of the consultation process. Community stakeholders agreed on a development strategy for the Hurunui catchment that would improve water quality in the tributaries and maintain quality in the main river. Results from the choice experiment support this approach. Willingness to pay for improvements in the main river was limited but residents would require substantial compensation before they would accept a decline in water quality in the main river or in the tributaries.
\end{abstract}

Keywords: choice experiment; water quality; New Zealand; environmental decision making; community consultation 


\section{Introduction}

Choice experiments can be designed using information gathered in stakeholder consultation processes. Information from these two sources can be used to consider both consultation outcomes and population preferences in environmental decision making. This approach is demonstrated using a case study of New Zealand's Hurunui River which has been hotly contested between those who seek to divert water and increase agricultural production and those who would like to see the river undeveloped and the natural resources in the river and catchment improved.

Clean, fresh water has long been close to the heart of the majority of New Zealanders. "Fresh water is a major driver of our economy, it sustains our unique environment, it is deeply embedded in our culture and life-style, and for many of us it is part of our identity. Fresh water is one of New Zealand's most important advantages-It is a national [treasure]" [1].

Water remains relatively clean and abundant in New Zealand but there has been a steadily increasing level of concern over declining water quality in lowland rivers and streams and in nationally significant lakes. At the same time, water is also causing disputes- "Disputes about Water Conservation Orders and water infrastructure development; disputes about the intensification of farming and about run-off; disputes about water infrastructure in cities and towns, its discharges, and how it should be organised and paid for; disputes about who should be involved in its management... " [1].

The Land and Water forum emerged in 2009 from a belief that New Zealand has often made a poor job of managing water. Key stakeholders came together in the forum to work collaboratively towards improved water management and have built substantial agreement in support of a new fresh water management framework:

Communities will collaborate (within a national regulatory framework and assisted by national guidance) to identify the specific issues in each catchment, set objectives and limits, and decide on solutions to address those issues effectively and meet their aspirations. All activities in the catchment which have an impact on water quality and flow will be accounted for and brought into the management framework. This in turn will create a more transparent, secure and enabling environment for business and investment decisions.

At the same time, the Canterbury Regional Council (Environment Canterbury) wished to develop an approach to managing catchment nutrient loads across the region in order to achieve the objectives of its Natural Resources Regional Plan (NRRP) for water quality and aquatic habitats. This approach, now recommended by $\mathrm{CRC}$ and partner organisations, involved extensive stakeholder consultation. It aligns well with the recommendations of the Land and Water Forum. This paper describes a method for using the stakeholder consultation process to design and implement a rank-ordered choice experiment.

Discrete choice experiments have been used widely in environmental valuation since the earliest application by Boxall et al. [2]. They are well-suited to situations where policy alternatives have multiple impacts and the objective is to estimate the value of these impacts. Rank-ordered choices provide richer preference information than methods which elicit only the favourite choice [3] since the marginal benefit of asking repeated questions about alternatives within a choice situation is generally greater than the marginal cost. 
The Hurunui River is widely regarded as being the most scenic and unspoilt of the seven major alpine rivers in the Canterbury Region of New Zealand's South Island (see Figure 1). From its headwaters in the Southern Alps, the Hurunui Rivers flows through alpine lakes and foothills before crossing the Amuri Plains and flowing through a gorge on its way to the Hurunui Estuary about 200 kilometres from its source. The river is highly significant to Ngai Tahu and nationally important for fishing and kayaking. It also provides an important habitat for a number of endangered fish and bird species [4].

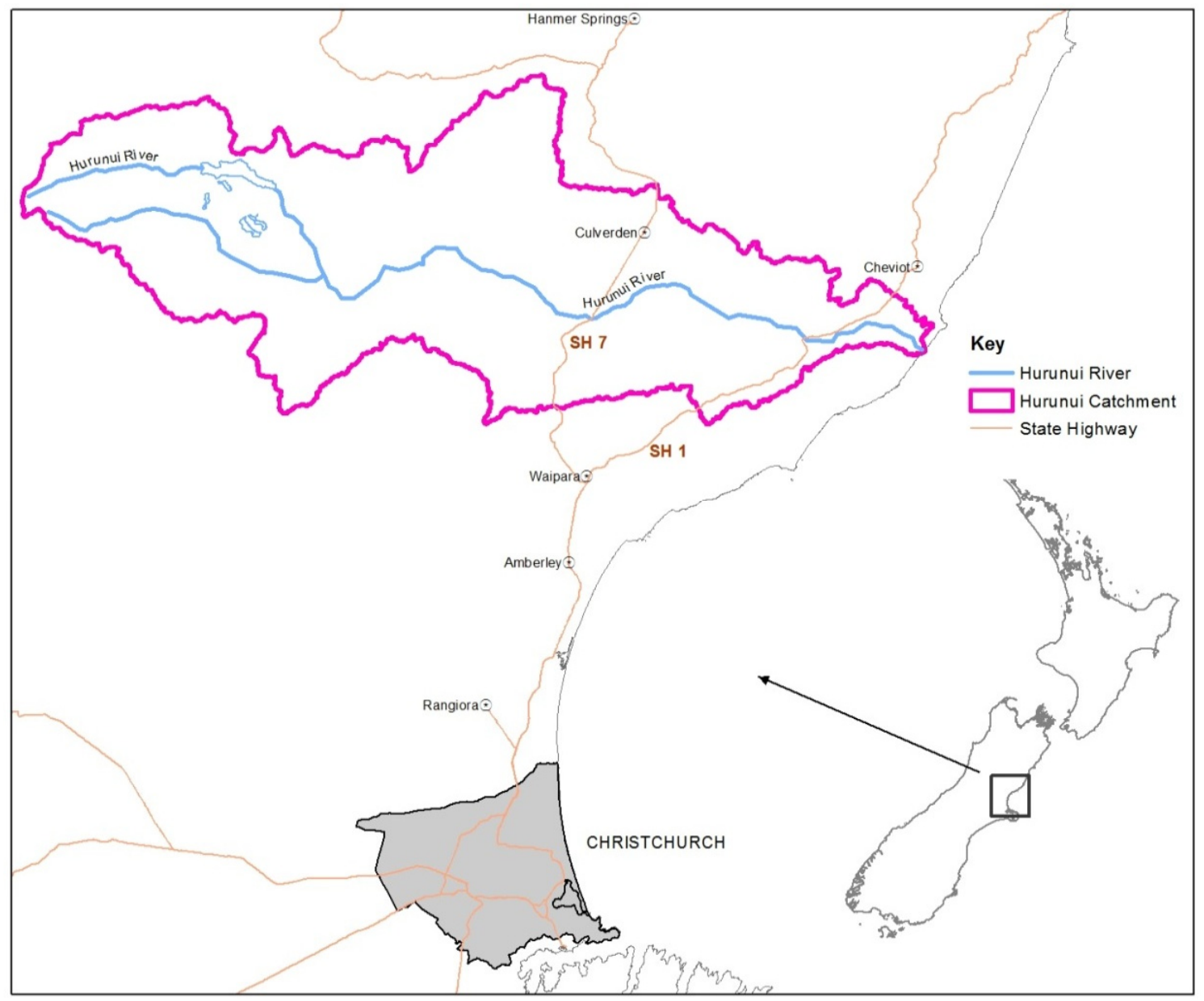

Figure 1. Location of the Hurunui River and catchment.

The future of the Hurunui River and its catchment has been hotly contested between those who seek to store and/or divert water from the river in order to increase agricultural production and those who would like to see the river undeveloped and the quality of natural resources in the river and catchment improved. The Canterbury Regional Council, concerned about the cumulative effects of intensive land use on surface and ground water quality, developed an approach to managing catchment nutrient loads across the region aimed at achieving the objectives of its Natural Resources Regional Plan (NRRP) for water quality and aquatic habitats. One approach, drawing on deliberative and systems methods, was developed and tested in the Hurunui catchment as part of the Land Use and Water Quality Project. The Land Use and Water Quality Project involved three distinct work streams: policy, science and community issues. It included stakeholder workshop groups addressing issues at a regional level and a series of catchment level stakeholder workshops held in the Hurunui District in November 2010. The 
workshops benefited from findings from the policy and science streams. A key project outcome was the drafting of a preferred approach for the management of the cumulative impacts of land use on water quality in the catchment $[5,6]$.

A scenario approach was used in order to assess "the acceptability of a range of environmental, economic, social and cultural outcomes for the catchment ..." [5]. This was based on an analysis of the current situation in the catchment alongside alternative future scenarios and 'business as usual' (Table 1). Stakeholders reached a general consensus that scenario six 'would 'probably' achieve the Canterbury Natural Resources Regional Plan objectives" [6]. This scenario requires that water quality be maintained at "2005-2009" nutrient levels in the Hurunui main stem and be returned to 1990-1995 water quality in the tributaries.

Table 1. Future land use scenarios.

\begin{tabular}{lll}
\hline No. & Scenario & Description \\
\hline 1 & Current land use & Based on current land use. \\
\hline 2 & Business as usual * & $\begin{array}{l}\text { Some intensification in line with historic trends. } \\
\text { All border dyke irrigation converted to spray irrigation. }\end{array}$ \\
\hline 3 & Intensive irrigation * & $\begin{array}{l}\text { Full irrigation of suitable land. All border dyke irrigation converted } \\
\text { to spray irrigation. }\end{array}$ \\
\hline 4 & Conservative & $\begin{array}{l}\text { All productive land was converted to forestry, aimed at achieving the } \\
\text { highest level of confidence of meeting NRRP objectives for periphyton. }\end{array}$ \\
\hline 5 & $\begin{array}{l}\text { 1990-1995 } \\
\text { Hurunui Water Quality }\end{array}$ & $\begin{array}{l}\text { A combination of some land use change and mitigations that aim to } \\
\text { meet water quality as it was in the Hurunui River in the early 1990s. } \\
\text { All border dyke irrigation converted to spray irrigation. }\end{array}$ \\
\hline 2005-2009 & $\begin{array}{l}\text { A staged approach to achieving a combination of some land use } \\
\text { change and mitigations that aim to meet water quality as it was in the } \\
\text { 1990-1995 } \\
\text { Water Quality in Tributaries }\end{array}$ & $\begin{array}{l}\text { Hurunui River in 2005 to 2009 and in the tributaries in 1990 to 1995. } \\
\text { All border dyke irrigation converted to spray irrigation. }\end{array}$ \\
\hline
\end{tabular}

Notes: * Assumes current land use practice; no additional mitigation. Source: Adapted from Brown et al. [6].

The policy objective of the choice experiment outlined in this paper was to describe and quantify the preferences of Canterbury Region residents regarding existing conditions (the status quo) and potential future land use and water quality scenarios for the catchment. In particular, the study involves estimates of the amount Canterbury region residents would be willing to pay (WTP) for improvement in water quality attributes and the level of compensation that they would be willing to accept (WTA) for deterioration in water quality attributes (referred to as "values" in the stakeholder workshops and in Wedderburn et al. [5]). This quantitative information on preferences across the region was provided to policy makers as they considered the outcomes of the stakeholder deliberative process.

\section{Survey Design and Methods}

\subsection{Attribute Selection}

Attributes selected for inclusion in the choice experiment were determined using data from the catchment level stakeholder workshops held as part of the consultation process. The qualitative 
methods used to identify the most important attributes for different stakeholders are described in Wedderburn et al. [5]. Participating stakeholders were chosen by regional council staff to represent the views of local government, agricultural and forestry sectors, senior school students, energy companies, health workers, farmers, agribusiness companies, environmental groups, central government departments and recreational users.

Stakeholder selection was intended to represent all groups who are currently affected by water quality related issues and those who may be impacted by any policy or action to address the problem. Stakeholder groups were presented with details of alternative scenarios and asked to select and weight a set of the most important attributes, they believed would be impacted by the scenarios. In order to provide an overview of the most reported stakeholder concerns, the attributes and weights reported by each stakeholder group were classified into categories and summed across all groups. The outcome is shown in Table 2. Four of the five top-ranked attribute categories were included in the final design of the choice experiment. Given the local political environment and a history of disagreement over the future of the Hurunui River, the regional council had decided to consult separately on issues of water quality (this study) and water quantity (ranked 4th) which is not included in this study.

Table 2. Qualitative attribute scores from stakeholder consultation exercises.

\begin{tabular}{cccc}
\hline Rank & Attribute Category & Category Score & Percent \\
\hline 1 & Water quality & 145.25 & $13 \%$ \\
2 & Ecosystems and biodiversity & 130.25 & $12 \%$ \\
3 & Enterprise profitability & 118.75 & $11 \%$ \\
4 & Water quantity and reliability & 117 & $11 \%$ \\
5 & Community services and economy & 116.25 & $11 \%$ \\
6 & "Other" attributes (several) & 69 & $6 \%$ \\
7 & Community wellbeing & 53 & $5 \%$ \\
8 & Water quality-Drinking and stock & 46.5 & $4 \%$ \\
9 & Unobstructed flow & 46 & $4 \%$ \\
10 & Employment and jobs & 41 & $4 \%$ \\
11 & Soil health and fertility & 37 & $3 \%$ \\
12 & Water flows & 34 & $3 \%$ \\
13 & Heritage protection and history & 30.5 & $3 \%$ \\
14 & Regulations and compliance & 29 & $3 \%$ \\
15 & Public access & 24 & $2 \%$ \\
16 & Cultural values & 23 & $2 \%$ \\
17 & Landscape and trees & 20 & $2 \%$ \\
18 & Weed/pest disease management & 10 & $1 \%$ \\
19 & Water use efficiency & 9.5 & $100 \%$ \\
\hline & Total & -- &
\end{tabular}

Attribute selection and survey design was also determined by discussion with environmental economists familiar with local water quality issues and with technical experts assisting with development of the "preferred approach". Advice from experts developing the preferred approach was also used to define attributes and levels for a range of future scenarios. The final set of six attributes selected were suitability for swimming and recreation, ecological health, salmon and trout populations, tributary water quality and changes in number of jobs in the region. 
Since some scenarios would result in a reduction in environmental quality, respondents were asked to choose between options where local taxes were increased, indicating a willingness to pay for improved environmental quality or decreased, indicating a willingness to accept compensation for reduced quality. A specific attribute describing water quality in tributaries was included in order to better understand the relative importance of water quality in the main river (currently satisfactory) versus the lowland tributaries (currently not satisfactory).

\subsection{Defining Attribute Levels}

The attribute levels in the choice experiment were determined primarily by using the analysis provided under the science stream of the land use and water quality project. Scientists working on this stream described the current state of water quality in the Hurunui River and its tributaries as well as expected conditions under alternative scenarios, e.g., "business as usual" and agricultural intensification. An example of the science-based data used to assist this process is shown in Table A1. These data were translated into levels which would be understandable to the general public.

With a view to ensuring policy relevance, we made use of the minimum standards set by Canterbury Regional Council in defining attribute levels. An attribute that meets the minimum standard is defined as "satisfactory". If it does not it is 'unsatisfactory'. Exceeding the minimum standard is defined as "good". Tributary water quality is currently unsatisfactory and expected to decline under some scenarios so an extra level "poor" was added to represent this decline. The levels for changes in jobs were based on potential effects on the agricultural sector and the wider economy resulting from different water management scenarios, drawing on work by Simon Harris, described in Brown et al. [6]. The levels are: 250 fewer jobs, no change, 250 more jobs or 500 more jobs. The final set of attributes and levels are shown in Table A2.

\subsection{Pilot, Pre-Test and Final Survey Design}

Early versions of the questionnaire were piloted with selected workshop participants, Canterbury residents and technical experts. At this stage interviewees were debriefed on their experience in filling in the questionnaire with the survey instrument being improved and clarified as a result. An on-line version of the questionnaire was then pretested using Canterbury region residents. Respondents for the final version of the survey were recruited from an online market research panel in June 2011 and invited to fill in the survey online. There were quotas on age, gender and education level in order to help achieve a representative sample. People who resided outside the Canterbury region were excluded. We also excluded the five per cent of people who completed the survey in less than five minutes since in our judgment they would not have been able to properly assess the different choice cards in such a short period of time.

Figure 2 is an example of a choice card as it was presented to participants. When participants selected an alternative it was hidden and they were then instructed to select another alternative until they had ranked all alternatives on each choice card. They were then shown their ranking results and asked to confirm these before proceeding to the next card. 


\begin{tabular}{|c|c|c|c|c|c|c|}
\hline \multicolumn{7}{|c|}{ Choice card 1 of 6} \\
\hline & & Current Situation & Scenario $\mathrm{A}$ & Scenario B & Scenario C & Scenario D \\
\hline & $\begin{array}{l}\text { Suitability for } \\
\text { Swimming and } \\
\text { Recreation }\end{array}$ & $\begin{array}{c}\text { Satisfactory } \\
v\end{array}$ & $\begin{array}{c}\text { Good } \\
w\end{array}$ & $\begin{array}{c}\text { Not Satisfactory } \\
x\end{array}$ & $\begin{array}{c}\text { Satisfactory } \\
v\end{array}$ & $\begin{array}{c}\text { Good } \\
w\end{array}$ \\
\hline $\begin{array}{l}\text { Main } \\
\text { river }\end{array}$ & Ecological Health & $\begin{array}{c}\text { Satisfactory } \\
v\end{array}$ & $\begin{array}{c}\text { Not Satisfactory } \\
x\end{array}$ & $\begin{array}{c}\text { Not Satisfactory } \\
x\end{array}$ & $\begin{array}{c}\text { Not Satisfactory } \\
x\end{array}$ & $\begin{array}{c}\text { Good } \\
w\end{array}$ \\
\hline$=$ & $\underline{\text { Salmon and Trout }}$ & $\begin{array}{c}\text { Satisfactory } \\
v\end{array}$ & $\begin{array}{c}\text { Satisfactory } \\
v\end{array}$ & $\begin{array}{c}\text { Good } \\
w\end{array}$ & $\begin{array}{c}\text { Satisfactory } \\
v\end{array}$ & $\begin{array}{c}\text { Not Satisfactory } \\
x\end{array}$ \\
\hline Tributaries & $\begin{array}{l}\text { Tributary water } \\
\text { quality }\end{array}$ & $\begin{array}{c}\text { Not Satisfactory } \\
x\end{array}$ & $\begin{array}{c}\text { Good } \\
w\end{array}$ & $\begin{array}{c}\text { Satisfactory } \\
v\end{array}$ & $\begin{array}{c}\text { Not Satisfactory } \\
x\end{array}$ & $\begin{array}{l}\text { Poor } \\
x x\end{array}$ \\
\hline$-8 y^{2}$ & Number of Jobs & Stay about the same & Stay about the same & $\begin{array}{c}250 \\
\text { more jobs in region }\end{array}$ & Stay about the same & $\begin{array}{c}500 \\
\text { more jobs in region }\end{array}$ \\
\hline Economy & Cost to you & $\begin{array}{c}\$ 0 \\
\text { increase }\end{array}$ & $\begin{array}{c}\$ 75 \\
\text { increase }\end{array}$ & $\begin{array}{l}\$-100 \\
\text { decrease }\end{array}$ & $\begin{array}{c}\$ 25 \\
\text { increase }\end{array}$ & $\begin{array}{c}\$ 200 \\
\text { increase }\end{array}$ \\
\hline & & & & & & \\
\hline
\end{tabular}

Figure 2. Example of a choice card.

\subsection{Efficient Design}

A D-efficient design was generated in six blocks using the Ngene software package [7]. Efficient designs require a smaller number of respondents to achieve a given level of statistical significance of the parameters [8].

Information from other water quality non-market valuation studies in New Zealand such as [9,10] was used to estimate the initial Bayesian priors. Bayesian priors make the design efficiency more robust to misspecification than optimising with fixed priors [11]. The prior distributions were updated with values obtained from pilot tests of the survey. The design mean D-error was 0.21 with a standard deviation of 0.008 . The estimated sample size required was 84 . The actual sample was 505 and statistical significance was achieved for every attribute.

Rather than specifying cost as a continuous attribute we specified a large number of levels at \$25 increments between minus $\$ 100$ and $\$ 200$. A constraint was imposed so that each level appeared at least once in a block. This meant that participants saw a variety of costs without imposing too much of a penalty on design efficiency. A negative cost represents a decrease in the household's annual rates bill. Negative costs were required because water quality attributes are expected to decline under some scenarios of agricultural intensification. If cost was constrained to be positive it would be difficult to avoid dominated choice situations and design efficiency would be much lower.

\subsection{Choice Experiment Structure}

In this study we obtained full rankings of the five alternatives in each choice situation and used an exploded logit specification to take into account the sequential way in which the ranks are obtained [12]. The complete ranking of $J$ alternatives in a choice set is a sequence of $J$ - 1 discrete 
choices drawn without replacement from the starting set of five alternatives. The utility structure for each choice task is:

$$
U_{n j k}=\left(\lambda V_{n j k}+\varepsilon_{n j k}\right) \times \delta_{j}
$$

where $U$ is the utility for each task, $V$ is observed utility, $\varepsilon_{n j k}$ is the error term, $n$ are individual respondents, $j$ are the alternatives, $k$ is the number of alternatives remaining for each choice and $\delta_{j}$ denotes whether alternative $j$ is available or was selected previously. The scale parameter, or inverse Gumbel error, is denoted by $\lambda$. Observed utility or $V$ is a vector of linearly additive attributes for cost, jobs and environmental quality. It also includes some interaction terms for cost and individual-specific variables.

Participants in ranking tasks may be left to decide how to achieve full ranking or given specific instructions on the order in which to select the rankings as in [13]. One elicitation technique known as "best-worst" ranking involves asking respondents to choose sequentially the best and worst alternatives until all are ranked as in [14]. Researchers, however, could theoretically instruct participants to rank the alternatives in any order.

We divided the sample into two groups who were given different instructions. Half the respondents were directed to use a "best-worst" ranking technique and the other half were directed to repeatedly select their favorite from the alternatives remaining ("repeated best"). In both treatments, the first choice involved selecting the favorite alternative from a set of five. The favorite alternative was then hidden. Respondents in the best-worst treatment were then directed to select their least preferred option, while the other group was directed to select their next favorite. The process was repeated until the five alternatives were all ranked. In another paper [15] we test whether the elicitation method (best-worst versus repeated-best) has implications for the scale parameter.

\section{Results}

\subsection{Sample Statistics and Model Estimation}

Sample statistics for the final sample of 505 completed surveys are presented in Table 3. Comparison with data from the 2006 census suggests that the sample is broadly representative of the region although it should be noted that certain groups are over or under represented. In particular, our sample somewhat over represents females, those with a post-school qualification and those in the 18-30 age bracket and under represents low income households (less than \$30,000).

The fully-ranked choice sets were decomposed into a series of choices using the exploded logit specification detailed by [12]. The best-worst method results in different comparisons to the repeated-best method, which means the selection order needs to be taken into account in the decomposition. The sign of the utility parameters were reversed in situations where respondents were selecting the "worst" alternative.

We estimated four different models using the maximum (simulated) likelihood estimate in BIOGEME [16] and present the attribute coefficients that comprise observed utility $V_{\text {njk }}$ in Table 4. Model 1 is a fixed parameter MNL model which is a typical starting point. Model 2 is a fixed parameter MNL with scale parameterization (SP) to account for potential heteroskedasticity in the random component of choice across different rank levels [17], learning or fatigue effects [18] and 
individual cognitive ability [19]. Model 3 is a panel random parameters logit (RPL) model which allows for heterogeneity in attribute weights across individuals. Model 4 is a panel RPL with scale parameterization which models both taste heterogeneity and heteroskedasticity.

Table 3. Sample statistics.

\begin{tabular}{|c|c|c|c|}
\hline \multicolumn{2}{|c|}{ Treatment Group } & Sample & 2006 Census \\
\hline \multicolumn{2}{|c|}{ Count of participants } & 505 & 521,832 \\
\hline \multirow{2}{*}{ Gender } & Female & $58 \%$ & $51 \%$ \\
\hline & Male & $42 \%$ & $49 \%$ \\
\hline \multirow{4}{*}{ Age } & $18-30$ & $25 \%$ & $20 \%$ \\
\hline & $30-44$ & $30 \%$ & $29 \%$ \\
\hline & $45-59$ & $24 \%$ & $26 \%$ \\
\hline & Over 60 & $21 \%$ & $25 \%$ \\
\hline Post-school qualification & & $59 \%$ & $51 \% *$ \\
\hline \multirow{6}{*}{ Annual household income } & Less than $\$ 30,000$ & $18 \%$ & $22 \%$ \\
\hline & $\$ 30,000$ to $\$ 50,000$ & $19 \%$ & $20 \%$ \\
\hline & $\$ 50,000$ to $\$ 70,000$ & $20 \%$ & $21 \%$ \\
\hline & $\$ 70,000$ to $\$ 100,000$ & $18 \%$ & $19 \%$ \\
\hline & Greater than $\$ 100,000$ & $14 \%$ & $18 \%$ \\
\hline & Declined & $12 \%$ & \\
\hline \multirow{2}{*}{ Location of residence } & Christchurch city & $73 \%$ & $67 \%$ \\
\hline & Other Canterbury & $27 \%$ & $23 \%$ \\
\hline \multicolumn{2}{|c|}{ Involved in farming } & $7 \%$ & \\
\hline \multicolumn{2}{|c|}{ Seen the Hurunui or a tributary in last 12 months } & $41 \%$ & \\
\hline \multicolumn{2}{|c|}{ Visited the Hurunui or a tributary in last 12 months } & $15 \%$ & \\
\hline
\end{tabular}

Note: * Statistics New Zealand Household Labour Force Survey 2011.

\subsection{Results for Models 1 and 2; Assuming Homogeneous Preferences}

In the first MNL model, all the parameters except for "250 more jobs" are significant at least at the 5 percent level. All coefficients have the expected sign, with levels representing a decline in quality having negative values. The attributes which have two improvement levels, jobs and tributary water quality, have a larger coefficient for the best level, thereby conforming with the weak axiom of revealed preference. The parameters are not directly comparable between the two models but are similar in relative magnitude with some important exceptions detailed below.

The cost levels include both negative and positive values. We therefore use a piecewise linear specification similar to Hess, Rose, and Hensher [20] to account for asymmetry. Cost is normalised to take a similar range to the other parameters by dividing by $\$ 200$. The cost coefficient is negative and the negative cost dummy parameter is positive in all models. This is consistent with the endowment effect and means people are more willing to forgo a reduction in rates rather than spending their existing monetary endowment. 
Table 4. Results-Attribute coefficients and model fit.

\begin{tabular}{|c|c|c|c|c|c|c|c|c|c|}
\hline \multirow{2}{*}{ Attribute } & \multirow{2}{*}{ Measure } & \multicolumn{2}{|c|}{ Model 1 (MNL) } & \multicolumn{2}{|c|}{ Model 2 (MNL with SP) } & \multicolumn{2}{|c|}{ Model 3 (RPL) } & \multicolumn{2}{|c|}{ Model 4 (RPL with SP) } \\
\hline & & Coef. & $Z$-value & Coef. & $Z$-value & Coef. & $Z$-value & Coef. & $Z$-value \\
\hline \multirow{2}{*}{ Normalised Cost } & $\mu$ & $-0.652 * * *$ & -9.75 & $-0.340 * * *$ & -6.72 & $-1.070 * * *$ & -8.45 & $-0.242 * * *$ & -6.84 \\
\hline & $\sigma$ & & & & & $1.950 * * *$ & 17.71 & $-0.412 * * *$ & -8.07 \\
\hline \multirow{2}{*}{ Dummy for neg cost } & $\mu$ & $0.222 * *$ & 2.06 & 0.035 & 0.52 & $0.527 * * *$ & 3.25 & $0.084 * *$ & 2.38 \\
\hline & $\sigma$ & & & & & $-2.440 * * *$ & -9.31 & $0.453 * * *$ & 5.12 \\
\hline \multirow{2}{*}{ "Good" ecology } & $\mu$ & $0.134 * * *$ & 3.5 & $0.112 * * *$ & 4.57 & $0.264 * * *$ & 4.86 & $0.062 * * *$ & 5.05 \\
\hline & $\sigma$ & & & & & $-1.060 * * *$ & -9.96 & $-0.194 * * *$ & -7.02 \\
\hline \multirow{2}{*}{ "Unsatisfactory" ecology } & $\mu$ & $-0.713 * * *$ & -22.37 & $-0.440 * * *$ & -9.79 & $-0.999 * * *$ & -18.64 & $-0.213 * * *$ & -8.74 \\
\hline & $\sigma$ & & & & & $1.310 * * *$ & 16.85 & $0.210 * * *$ & 7.79 \\
\hline \multirow{2}{*}{ “Good" fishing } & $\mu$ & $0.064 * *$ & 2.15 & $0.067 * * *$ & 3.67 & $0.142 * * *$ & 3.48 & $0.041 * * *$ & 4.57 \\
\hline & $\sigma$ & & & & & $0.694 * * *$ & 6.98 & $-0.098 * * *$ & -4.45 \\
\hline \multirow{2}{*}{ "Unsatisfactory" fishing } & $\mu$ & $-0.671 * * *$ & -21.87 & $-0.409 * * *$ & -9.81 & $-0.955 * * *$ & -19.39 & $-0.202 * * *$ & -8.61 \\
\hline & $\sigma$ & & & & & $1.180 * * *$ & 12.46 & $-0.203 * * *$ & -7.11 \\
\hline \multirow{2}{*}{500 more jobs } & $\mu$ & $0.071 * *$ & 1.96 & $0.053 * * *$ & 2.57 & $0.158 * * *$ & 3.26 & $0.030 * * *$ & 3.14 \\
\hline & $\sigma$ & & & & & $0.650 * * *$ & 5.4 & $0.107 * * *$ & 4.22 \\
\hline \multirow{2}{*}{250 more jobs } & $\mu$ & 0.048 & 1.36 & $0.051 * * *$ & 2.53 & $0.095 * *$ & 2.01 & 0.014 & 1.49 \\
\hline & $\sigma$ & & & & & 0.172 & 0.23 & $0.050 *$ & 1.71 \\
\hline \multirow{2}{*}{250 less jobs } & $\mu$ & $-0.519 * * *$ & -15.65 & $-0.325 * * *$ & -8.91 & $-0.781 * * *$ & -14.79 & $-0.162 * * *$ & -8.12 \\
\hline & $\sigma$ & & & & & $-1.250 * * *$ & -14.62 & $0.206 * * *$ & 6.93 \\
\hline \multirow{2}{*}{ "Good" recreation } & $\mu$ & $0.216 * * *$ & 6.1 & $0.098 * * *$ & 4.31 & $0.269 * * *$ & 5.34 & $0.039 * * *$ & 3.59 \\
\hline & $\sigma$ & & & & & $0.886 * * *$ & 8.43 & $0.084 * * *$ & 2.5 \\
\hline \multirow{2}{*}{ "Unsatisfactory" recreation } & $\mu$ & $-0.784 * * *$ & -23.64 & $-0.513 * * *$ & -9.97 & $-1.130 * * *$ & -18.91 & $-0.246 * * *$ & -8.9 \\
\hline & $\sigma$ & & & & & $-1.510 * * *$ & -18.21 & $0.268 * * *$ & 7.98 \\
\hline \multirow{2}{*}{ “Good" tributaries } & $\mu$ & $0.552 * * *$ & 15.66 & $0.358 * * *$ & 9.46 & $0.858 * * *$ & 17.12 & $0.182 * * *$ & 8.82 \\
\hline & $\sigma$ & & & & & $-0.866 * * *$ & -8.36 & $0.065 * *$ & 2.21 \\
\hline \multirow{2}{*}{ "Satisfactory" tributaries } & $\mu$ & $0.362 * * *$ & 10.36 & $0.264 * * *$ & 8.42 & $0.582 * * *$ & 11.68 & $0.125 * * *$ & 8.02 \\
\hline & $\sigma$ & & & & & $0.928 * * *$ & 8.5 & $-0.063 *$ & -1.72 \\
\hline
\end{tabular}


Table 4. Cont.

\begin{tabular}{|c|c|c|c|c|c|c|c|c|c|}
\hline \multirow{2}{*}{ Attribute } & \multirow{2}{*}{ Measure } & \multicolumn{2}{|c|}{ Model 1 (MNL) } & \multicolumn{2}{|c|}{ Model 2 (MNL with SP) } & \multicolumn{2}{|c|}{ Model 3 (RPL) } & \multicolumn{2}{|c|}{ Model 4 (RPL with SP) } \\
\hline & & Coef. & $Z$-value & Coef. & $Z$-value & Coef. & $Z$-value & Coef. & $Z$-value \\
\hline \multirow{2}{*}{ "Poor" tributaries } & $\mu$ & $-0.568 * * *$ & -16.98 & $-0.352 * * *$ & -8.8 & $-0.823 * * *$ & -15.13 & $-0.185 * * *$ & -8.09 \\
\hline & $\sigma$ & & & & & $-1.410 * * *$ & -15.53 & $0.262 * * *$ & 7.75 \\
\hline $\begin{array}{c}\text { Cost } * \text { post-school } \\
\text { education }\end{array}$ & $\mu$ & $0.244 * * *$ & 4.07 & $0.135 * * *$ & 3.66 & $0.237 *$ & 1.8 & $0.101 * * *$ & 3.64 \\
\hline Cost $*$ seen the site & $\mu$ & $0.269 * * *$ & 4.48 & $0.173 * * *$ & 4.59 & $0.541 * * *$ & 3.92 & $0.101 * * *$ & 3.65 \\
\hline Status quo & $\mu$ & $0.266 * * *$ & 6.84 & $0.098 * * *$ & 4.08 & $0.364 * * *$ & 7.72 & $0.040 * * *$ & 3.94 \\
\hline Log-likelihood & & $-12,219$ & & $-11,916$ & & $-11,458$ & & $-11,316$ & \\
\hline AIC & & 2.02 & & 1.97 & & 1.90 & & 1.87 & \\
\hline $\mathrm{BIC}$ & & 2.03 & & 1.99 & & 1.91 & & 1.90 & \\
\hline Adjusted McFadden $r^{2}$ & & 0.16 & & 0.18 & & 0.21 & & 0.22 & \\
\hline
\end{tabular}


Among the other parameters, the absolute value of the negative coefficients are larger than the improvement parameters. This is a common finding in studies comparing WTP and WTA [21]. The WTA to avoid 250 jobs lost is much higher than the WTP to gain 500 jobs. As the other parameters have categorical levels, the degree of asymmetry cannot be determined. The status quo parameter is significant and positive in both models, indicating that respondents slightly preferred the "no change" scenario, other things being equal. The status quo bias is another manifestation of loss aversion [22]. In Model 2, the status quo parameter is relatively lower compared with all other attributes. This may be another effect of controlling for scale variation caused by negative cost alternatives.

A large number of interaction terms were tested. The two terms that were consistently significant were the cost $\times$ post school education interaction and cost $\times$ seen where post school education is a dummy indicating whether an individual has completed a post school qualification while "seen" is a dummy variable indicating the individual has personally seen the Hurunui River or its tributaries. Both of these interactions are positive, which means that people who have more education, or have seen the site, tend to be willing to pay more for environmental quality. Income and education are highly correlated so the education interaction effect is probably a combination of income effect and environmental awareness.

Scale parameters are not reported here but the rank and sequence dependent parameters were all significant and the expected sign, as were variables for participant understanding and time spent on task (measures of cognitive ability and effort).

\subsection{Results for Models 3 and 4; Assuming Heterogeneous Preferences}

Models 3 and 4 are panel mixed logit models with random parameters for cost, jobs, and environmental attributes. The unconditional mean parameter estimates are very similar to those in the fixed parameter models. Five hundred Halton draws were used to estimate the random parameters. Uniform distributions were used because this carries a lower risk of misspecification than less flexible distributions [23]. The RPL models have improved model fit, with adjusted McFadden $r$-squared values 0.21 and 0.22 vs. 0.16 and 0.18 for Models 1 and 2 .

The negative cost dummy parameter is relatively larger in the RPL models. Similarly to the MNL models, the inclusion of the scale parameter has the effect of reducing the relative magnitude of the negative cost and status quo parameters. There is a small decrease in variance of the asymmetry as well.

Most of the random parameters standard deviations are significant at the one percent per cent level. In Model 3, the standard deviation for "250 more jobs" is not significantly different to zero. In Model 4, "250 more jobs" and "satisfactory tributaries" are significant at the 10 percent level only, while "good tributaries" is significant at five percent. Almost all of the random parameter standard deviations are smaller in Model 4 than in Model 3. The exception is " 250 more jobs", but neither the means nor standard deviations were statistically significant for this parameter in either model. It appears that failing to control for scale variation in Model 3 magnified the estimated variance in individual preferences, as predicted by Louviere [14]. 


\subsection{Willingness to Pay}

Willingness-to-pay for an improvement in environmental quality, or willingness-to-avoid a decline in quality, is calculated by dividing the attribute coefficient by the cost coefficient. Due to asymmetry in our cost parameter, we report two sets of unconditional mean WTP/WTA values for each model in Table 5. The first column for each model is WTP/WTA under a situation where the household faces an overall increase in rates. The second column is WTP/WTA in a situation where household faces an overall decrease in rates. We also include the effect of cost $\mathrm{x}$ education and cost $\times$ seen interactions by using the population mean for education and, due to a lack of population data, the sample mean for the number of people who have seen the river.

Table 5. Mean Marginal willing to pay (WTP) or willing to accept (WTA) under Cost Increase or Decrease Scenarios.

\begin{tabular}{|c|c|c|c|c|c|c|}
\hline \multirow[t]{2}{*}{ Attribute } & \multicolumn{2}{|c|}{$\begin{array}{c}\text { Model } 3 \\
\text { (Random Parameters) }\end{array}$} & \multicolumn{2}{|c|}{$\begin{array}{c}\text { Model } 4 \\
\text { (Including Scale Parameters) }\end{array}$} & \multicolumn{2}{|c|}{$\begin{array}{c}\text { Model } 5 \\
\text { (Excluding Non-Attenders to Cost) }\end{array}$} \\
\hline & Cost Increase & Cost Decrease & Cost Increase & Cost Decrease & Cost Increase & Cost Decrease \\
\hline "Good" ecology & $\$ 74$ & $\$ 290$ & $\$ 88$ & $\$ 219$ & $\$ 44$ & $\$ 67$ \\
\hline "Unsatisfactory" ecology & $-\$ 282$ & $-\$ 1098$ & $-\$ 302$ & $-\$ 753$ & $-\$ 166$ & $-\$ 254$ \\
\hline "Good" fishing & $\$ 40$ & $\$ 156$ & $\$ 58$ & $\$ 143$ & $\$ 25$ & $\$ 39$ \\
\hline "Unsatisfactory" fishing & $-\$ 269$ & $-\$ 1049$ & $-\$ 287$ & $-\$ 714$ & $-\$ 160$ & $-\$ 244$ \\
\hline "Good" recreation & $\$ 76$ & $\$ 296$ & $\$ 55$ & $\$ 136$ & $\$ 33$ & $\$ 50$ \\
\hline "Unsatisfactory" recreation & $-\$ 319$ & $-\$ 1242$ & $-\$ 349$ & $-\$ 869$ & $-\$ 206$ & $-\$ 315$ \\
\hline "Good" tribs & $\$ 242$ & $\$ 943$ & $\$ 258$ & $\$ 643$ & $\$ 147$ & $\$ 225$ \\
\hline "Satisfactory" tribs & $\$ 164$ & $\$ 640$ & $\$ 177$ & $\$ 442$ & $\$ 87$ & $\$ 133$ \\
\hline "Poor" tribs & $-\$ 232$ & $-\$ 904$ & $-\$ 262$ & $-\$ 654$ & $-\$ 147$ & $-\$ 224$ \\
\hline 500 more jobs & $\$ 45$ & $\$ 174$ & $\$ 43$ & $\$ 106$ & $\$ 29$ & $\$ 44$ \\
\hline 250 more jobs & $\$ 27$ & $\$ 104$ & $\$ 19$ & $\$ 48$ & $\$ 23$ & $\$ 35$ \\
\hline 250 less jobs & $-\$ 220$ & $-\$ 858$ & $-\$ 230$ & $-\$ 572$ & $-\$ 135$ & $-\$ 205$ \\
\hline
\end{tabular}

For brevity, we report the results for three models. Model 3 is the RPL model, Model 4 is RPL with scale parameters, and Model 5 is the same as Model 4 except a latent class is used to exclude people who did not attend to (or ignored) the cost attribute following the method used by [22]. Non-attendance to cost is a form of protest behavior in which people select the scenario which gives their preferred environmental outcome regardless of the cost. No relative implicit price can be calculated for these individuals, and pooling the data will lead to upward biased welfare estimates. The authors of [24] provide an in-depth explanation of attribute non-attendance and the latent class method. We find that only 36 percent of individuals attend to the cost parameter under a latent class framework with different attribute coefficients constrained to zero. In Model 4, the difference between the two columns of WTP/WTA values is smaller than in Model 3 due to the smaller estimated asymmetry effect. In Model 5, all the values are smaller in magnitude, as expected.

\subsection{Distribution of Willingness to Pay}

Plots of individual specific estimates of willingness-to-pay provide a valuable illustration for policymakers of the range of preferences for different attributes. The distributions of individual WTP 
and WTA plotted in Figures 3 and 4 were estimated using model 5, the random parameters logit with scale parameters for full-attenders only. Kernel density (on the y axis) indicates relative frequency for each WTP/WTA value.

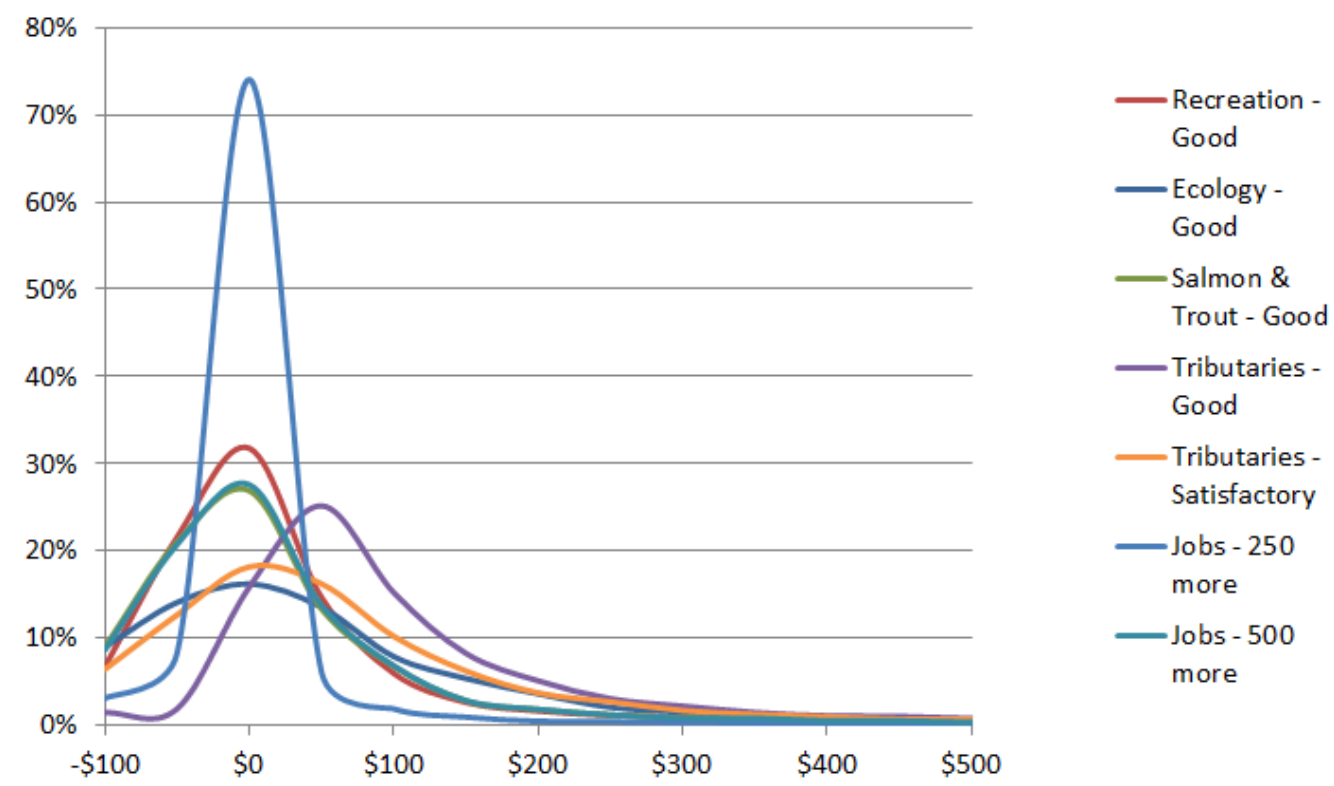

Figure 3. Distribution of WTP for Improvements (Model 5).

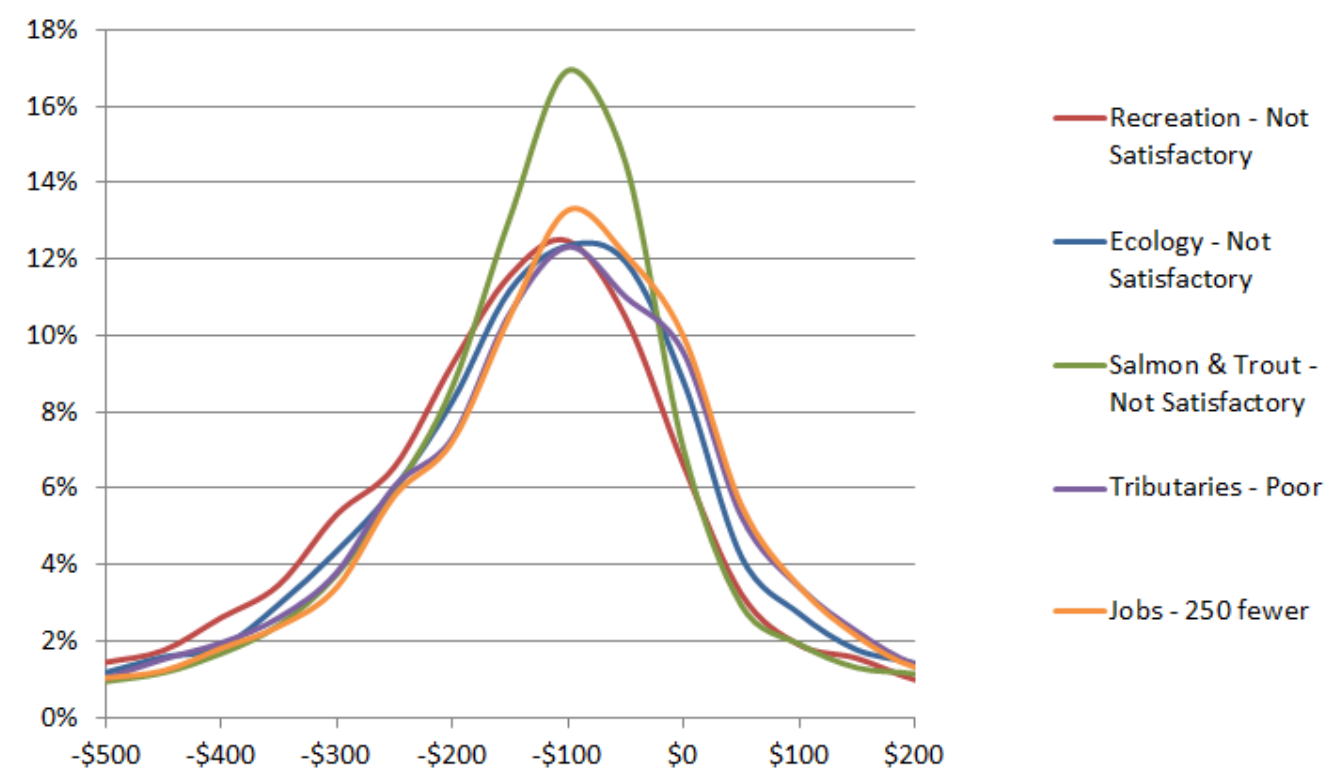

Figure 4. Distribution of WTA for Declines (Model 5).

These results provide a useful illustration of the spread of WTP/WTA values across the population. For example, preferences for more jobs (250 or 500 more) are tightly distributed within the range $-\$ 50$ to $+\$ 50$ (Figure 2). It can be seen that a sizeable minority are not concerned about the job attribute thereby leading to negative value estimates. Preferences for water quality, that is, of good quality for salmon, are more widely distributed ranging from negative values (not concerned) up to $\$ 300$. The distribution of WTP for good water quality in tributaries suggests that most respondents have a positive WTP ranging from $\$ 0$ to more than $\$ 300$ per household per year. 


\section{Discussion and Conclusions}

This study contributes to the literature in two main ways. First, it demonstrates a method for designing a choice experiment using information gathered in a stakeholder consultation process and shows that the information from these two sources may assist environmental decision making. Second it contributes to our knowledge of the willingness-to-pay for improved water quality in New Zealand. We have provided quantitative information on the preferences of Canterbury Region residents that should assist decision-making about the development of the Hurunui catchment. Elsewhere based on the same data set we investigate methodological issues relating to scale variation and the ranking of alternatives in choice experiments [15].

There has been rapid policy development since data collection for this research in November 2010. At national level the National Policy Statement on Freshwater Management 2014 [25] defines specific, measureable, water quality targets for ecosystem health and human health for recreation and sets out a local and regional process for managing fresh water. At local level, the Hurunui and Waiau River Regional Plan became operative in 2013 and seeks to maintain water quality in the Hurunui River "at about the same or better standard as present" [26].

We found that the property rights of Canterbury region residents had a major effect on the magnitude of our value estimates. Specifically, WTA greatly exceed WTP for a similar change in environmental quality. This finding is consistent with empirical results reported in the literature [2730] and by Horowitz and McConnell [31] who found that disparities between WTP and WTA tend to be higher for public goods than private goods.

If it is assumed that residents have a right to clean water that is not declining in quality, then willingness to accept compensation for deterioration, provides the appropriate estimate of value. Using Model 5 (excluding non-attenders to cost), residents would require compensation of \$315 per household per year before they would accept a deterioration in water quality in the main river from "satisfactory for recreation" to "unsatisfactory". Likewise they would require compensation of \$254 for a similar reduction in ecology or $\$ 244$ for a decline in suitability for salmon and trout, see Table 6.

One of the research questions addressed by the survey was the importance of water quality in the main river (currently satisfactory) vs. the lowland tributaries (currently not satisfactory). Would people, be willing to accept a decline in water quality in tributaries as long as water quality was maintained in the main river? Results from the choice experiment suggest that residents assign similar importance to these two attributes. They would, for example, require compensation of $\$ 224$ to accept a decline in tributary water quality from not-satisfactory to poor. This estimate is only 29 percent less than the $\$ 315$ that they would require to accept deterioration in the quality of the main river.

When water quality is currently satisfactory, and residents would like to see improvements, then willingness to pay provides the most appropriate measure. The following estimates are drawn from Model 5, for choices where residents faced an increase in cost. They would be willing to pay $\$ 33$, on average, to improve water quality in the main river from satisfactory to good, $\$ 44$ to improve ecology from satisfactory to good and $\$ 25$ to improve suitability for trout and salmon from satisfactory to good. Given that water quality in tributaries is currently not satisfactory, results from the cost decrease (compensation) column are more relevant. Residents, for example, would be willing to pay $\$ 133$ to increase water quality from not satisfactory to satisfactory. 
Table 6. Willingness to pay or accept compensation.

\begin{tabular}{|c|c|c|}
\hline Attribute & Level & Marginal Mean \\
\hline Suitability for swimming \& recreation & Not satisfactory & $-\$ 315$ \\
\hline Satisfactory to: & Good & $\$ 33$ \\
\hline Ecological health & Not satisfactory & $-\$ 254$ \\
\hline Satisfactory to: & Good & $\$ 44$ \\
\hline Salmon and trout & Not satisfactory & $-\$ 244$ \\
\hline Satisfactory to: & Good & $\$ 25$ \\
\hline \multirow{4}{*}{$\begin{array}{l}\text { Tributary water quality } \\
\text { Not Satisfactory to: }\end{array}$} & Poor & $-\$ 224$ \\
\hline & Satisfactory & $\$ 87$ ( $\$ 133$ for cost decrease) \\
\hline & Good & $\$ 147$ \\
\hline & 250 fewer jobs & $-\$ 205$ \\
\hline \multirow[t]{2}{*}{ Number of jobs in Canterbury } & 250 more jobs & $\$ 23$ \\
\hline & 500 more jobs & $\$ 29$ \\
\hline
\end{tabular}

Notes: WTP/WTA estimates are based on results for a cost decrease (for example, compensation) for deterioration and a cost increase for improvements. All results are from Model 5 and so exclude non-attenders to cost.

The jobs attribute provides information on preferences for increases or decreases in the number of jobs in the region. It also captures some associated concerns regarding the level of economic activity and services in rural areas. Furthermore, it provides a useful reminder to respondents that the regional economy may be affected by intensification or deintensification of agricultural land in the Hurunui catchment with the impact being measured in terms of job losses or gains compared with a "business-as-usual" scenario.

We find that the characteristics and order of magnitude of preferences for job losses or gains is similar to those revealed for the environmental attributes. Respondents selecting alternatives with a positive cost would be willing to pay $\$ 23$ for 250 more jobs in the region or $\$ 29$ for 500 more jobs. As with the environmental attributes our estimates of WTA are considerable higher; respondents would require compensation of $\$ 205$ before accepting an alternative that would results in 250 fewer jobs. It should be noted that these estimate for job losses should not be directly traded off against environmental attributes in a social cost benefit analysis. This avoids double counting of the employment effect, when the cost of mitigation policies already incorporates employment loss [32].

Findings from the choice experiment provide quantitative evidence that policymakers can consider at the same time as they consider the outcomes of the stakeholder deliberative process. This process arrived at "general acceptance" of a future development strategy for the Hurunui catchment that would maintain water quality in the main river at 2005-2009 levels, while requiring that actions are undertaken to return water quality in the tributaries to "1990-1995 water quality" [6]. Results from the choice experiment are broadly supportive of this approach. Canterbury region residents would require substantial compensation (mean \$244-\$315 per household per year) before they would accept a decline in water quality in the main river or in the tributaries. Willingness to pay for improvements in the main river is lower with a mean of $\$ 25-\$ 33$ per household per year. 


\section{Acknowledgments}

The authors thank the anonymous reviewers for constructive comments that greatly improved this manuscript. We also wish to thank the many people who were involved in the stakeholder workshops and who provided advice or feedback on our questionnaire, analysis and draft paper.

\section{Author Contributions}

Dan Marsh was mainly responsible for the initial research proposal, field work, consultations, survey and experimental design and policy analysis. Yvonne Phillips was mainly responsible for designing and implementing the web based survey and data analysis. Both authors contributed about equally to writing this paper.

\section{Appendix}

Table A1. Values and assessment by scenario (Hurunui River at Highway 1).

\begin{tabular}{|c|c|c|c|c|c|}
\hline & 4 & 5 & 1 & 2 & 3 \\
\hline Achieved for Each Scenario & Conservative & $\begin{array}{l}\text { 1990-1995 Water } \\
\text { Quality }\end{array}$ & Current Land Use & Business as Usual & Intensive Irrigation \\
\hline $\begin{array}{l}\text { NRRP periphyton objective } \\
\qquad\left(120 \mathrm{mg} / \mathrm{m}^{2}\right)\end{array}$ & Almost certainly & Almost certainly & Probably & Possibly? & Possibly? \\
\hline $\begin{array}{l}\text { Visual aesthetic values } \\
\text { ( }<20 \% \text { algae cover) }\end{array}$ & Almost certainly & Almost certainly & Probably & Possibly? & Possibly? \\
\hline Visual water clarity & Almost certainly & Almost certainly & Almost Certainly & Probably & Probably \\
\hline $\begin{array}{l}\text { Recreation values (safety, } \\
\text { microbiological health) }\end{array}$ & Almost certainly & Almost certainly & Probably & Possibly? & Possibly? \\
\hline $\begin{array}{c}\text { Benthic biodiversity (Invertebrates, } \\
\text { QMCI, EPTresponses to algae) }\end{array}$ & Almost certainly & Almost certainly & Probably & Possibly? & Possibly? \\
\hline $\begin{array}{c}\text { Trout habitat\& angling (based on } \\
\text { NZ periphyton guidelines) }\end{array}$ & Almost certainly & Almost certainly & Probably & Possibly? & Possibly? \\
\hline $\begin{array}{l}\text { Nitrate toxicity criteria to protect } \\
95 \% \text { aquatic species biodiversity } \\
\qquad(\sim 1.7 \mathrm{mg} / \mathrm{L})\end{array}$ & Almost certainly & Almost certainly & Almost Certainly & Almost Certainly & Almost Certainly \\
\hline $\begin{array}{l}\text { Nitrate toxicity criteria to protect } \\
\text { human drinking quality } \\
\qquad(\sim 11.3 \mathrm{mg} / \mathrm{L})\end{array}$ & Almost certainly & Almost certainly & Almost Certainly & Almost Certainly & Almost Certainly \\
\hline $\begin{array}{l}\text { Riverbed birds } \\
\text { (with respect to maintaining aquatic } \\
\text { food supplies only) }\end{array}$ & Almost certainly & Almost certainly & Probably & Possibly? & Possibly? \\
\hline Nga Tahu eco-cultural values & Unknown & Unknown & Unknown & Unknown & Unknown \\
\hline
\end{tabular}

Note: Source: Norton and Kelly [33] and updated version provided Norton 21 January 2011. 
Table A2. Attribute levels.

\begin{tabular}{|c|c|c|c|}
\hline Attribute & Attribute Description & $\begin{array}{l}\text { Current } \\
\text { Situation }\end{array}$ & Other Levels \\
\hline $\begin{array}{l}\text { Suitability for } \\
\text { Swimming and } \\
\text { Recreation } \\
\text { "Recreation" }\end{array}$ & $\begin{array}{l}\text { This is a combined measure of water clarity, algae } \\
\text { levels, and levels of e-coli bacteria. } \\
\text { Good: ECan objectives always met or exceeded. } \\
\text { Water always clear and safe and free of algae. } \\
\text { Satisfactory: ECan objectives usually met. } \\
\text { Water is usually clear and safe and free of algae. } \\
\text { Not satisfactory: ECan objectives not met. } \\
\text { Water is usually murky and unsafe; too much algae. }\end{array}$ & Satisfactory & $\begin{array}{l}\text { Not } \\
\text { Satisfactory } \\
\text { Good }\end{array}$ \\
\hline $\begin{array}{l}\text { Ecological } \\
\text { Health } \\
\text { "Ecology" }\end{array}$ & $\begin{array}{l}\text { This is a measure of the life-supporting capacity of } \\
\text { the river. It covers aquatic ecosystems, associated } \\
\text { significant habitats of indigenous fauna and areas of } \\
\text { significant indigenous vegetation. } \\
\text { Good: ECan objectives always met or exceeded. } \\
\text { Satisfactory: ECan objectives usually met. } \\
\text { Not Satisfactory: ECan objectives not met. }\end{array}$ & Satisfactory & $\begin{array}{l}\text { Not } \\
\text { Satisfactory } \\
\text { Good }\end{array}$ \\
\hline $\begin{array}{l}\text { Salmon and } \\
\text { Trout } \\
\text { "Fishing" }\end{array}$ & $\begin{array}{l}\text { This is a measure of the life-supporting capacity of } \\
\text { the river for trout and salmon. } \\
\text { Good } \\
\text { Satisfactory } \\
\text { Not satisfactory } \\
\text { (As above) }\end{array}$ & Satisfactory & $\begin{array}{l}\text { Not } \\
\text { Satisfactory } \\
\text { Good }\end{array}$ \\
\hline $\begin{array}{c}\text { Tributary } \\
\text { Water Quality }\end{array}$ & $\begin{array}{l}\text { This is an overall measure of the health of Hurunui } \\
\text { tributaries. It covers water clarity, sedimentation, } \\
\text { algal growth, suitability for contact recreation, } \\
\text { ecosystem health and habitat values. (As above). }\end{array}$ & $\begin{array}{c}\text { Not } \\
\text { Satisfactory }\end{array}$ & $\begin{array}{l}\text { Poor } \\
\text { Satisfactory } \\
\quad \text { Good }\end{array}$ \\
\hline $\begin{array}{c}\text { Number of Jobs } \\
\text { "Jobs" }\end{array}$ & $\begin{array}{l}\text { The regional economy may be affected by } \\
\text { intensification or de-intensification of agricultural } \\
\text { land in the Hurunui catchment. The impact is } \\
\text { measured in terms of job losses or gains compared } \\
\text { with a business-as-usual scenario. }\end{array}$ & $\begin{array}{c}\text { Stay about the } \\
\text { same }\end{array}$ & $\begin{array}{l}250 \text { less jobs, } \\
250 \text { more jobs, } \\
500 \text { more jobs } \\
\text { in the region }\end{array}$ \\
\hline $\begin{array}{l}\text { Cost to You } \\
\text { "Cost" }\end{array}$ & $\begin{array}{l}\text { There may be an increase or decrease in local or } \\
\text { national taxes as a result of this scenario. This is the } \\
\text { net cost to you, per year, for the next } 10 \text { years. }\end{array}$ & $\$ 0$ & $\begin{array}{l}\text { \$200 increase } \\
\$ 75 \text { increase } \\
\$ 25 \text { increase } \\
\$ 25 \text { decrease } \\
\$ 50 \text { decrease } \\
\text { \$100 decrease }\end{array}$ \\
\hline
\end{tabular}

Note: All attributes have four levels including the status quo, while the payment variable (Cost to Household) has six levels. 
Table A3. Results: Mixed Logit Model used for Figures 2 and 3.

\begin{tabular}{cccc}
\hline Attribute & Outcome & Mean & Standard Deviation \\
\hline Cost & & $-0.003 * * *$ & $0.003 * * *$ \\
Suitability for Swimming & Not Satisfactory & $-1.030 * * *$ & $1.415 * * *$ \\
And Recreation & Good & $0.209 * * *$ & $0.826 * * *$ \\
\hline Satisfactory to: & & & \\
Ecological Health & Not Satisfactory & $-0.842 * * *$ & $1.323 * * *$ \\
\hline Satisfactory to: & Good & $0.221 * * *$ & $0.901 * * *$ \\
Salmon and Trout & Not Satisfactory & $-0.828 * * *$ & $0.991 * * *$ \\
\hline Satisfactory to: & Good & $0.150 * * *$ & $0.592 * * *$ \\
Tributary Water Quality & Poor & $-0.741 * * *$ & $1.132 * * *$ \\
\hline Not Satisfactory to: & Satisfactory & $0.528 * * *$ & $0.790 * * *$ \\
& Good & $0.742 * * *$ & $0.680 * * *$ \\
\hline Number of Jobs in & 250 Fewer Jobs & $-0.663 * * *$ & $0.904 * * *$ \\
Canterbury & 250 More Jobs & $0.081 *$ & 0.046 \\
\hline No change to: & 500 Fewer Jobs & $0.125 * * *$ & $0.293 *$ \\
Status quo & & $0.386 * * *$ & \\
\hline & Notes: $P<0.10 ; * * *<0.01$. &
\end{tabular}

\section{Conflicts of Interest}

The authors declare no conflict of interest.

\section{References}

1. Third Report of the Land and Water Forum: Managing Water Quality and Allocating Water. Available online: http://www.landandwater.org.nz/includes/download.aspx?ID=124767 (accessed on 14 April 2015).

2. Boxall, P.C.; Adamowicz, W.L.; Swait, J.; Williams, M.; Louviere, J. A comparison of stated preference methods for environmental valuation. Ecol. Econ. 1996, 18, 243-253.

3. Hausman, J.A.; Ruud, P.A. Specifying and testing econometric models for rank-ordered data. J. Econ. 1987, 34, 83-104.

4. Potential Moratorium on the Hurunui River and Its Tributaries. Available online: http://beehive. govt.nz/sites/all/files/nz_19_July_letter_to_Minister_for_the_Environment.pdf (accessed on 14 April 2015).

5. Wedderburn, L.; Bewsell, D.; Blackett, P.; Brown, M.; Kelly, S.; Mackay, M.; Maani, K.; Montes, O.; Payne, T. Developing a Preferred Approach for Managing the Cumulative Effects of Land Uses on Freshwater Quality; Report prepared for P21 environment programme and Environment Canterbury; Environment Canterbury: Canterbury, New Zealand, 2011.

6. Brown, I.; Norton, N.; Wedderburn, L.; Monaghan, R.M.; Harris, S.; Hayward, S.; Ford, R. Nutrient Management in Hurunui: A Case Study in Identifying Options and Opportunities; Environment Canterbury: Canterbury, New Zealand, 2011.

7. Institute of Transport and Logistics Studies. Ngene-A Software Capability to Design and Generate Choice Experiments; The University of Sydney: Sydney, Australia, 2007. 
8. Scarpa, R.; Rose, J.M. Design efficiency for non-market valuation with choice modelling: How to measure it, what to report and why. Aust. J. Agric. Resour. Econ. 2008, 52, 253-282.

9. Marsh, D.; Mkwara, L.; Scarpa, R. Do respondents' perceptions of the status quo matter in non-market valuation with choice experiments? An application to New Zealand freshwater streams. Sustainability 2011, 3, 1593-1615.

10. Tait, P.; Baskaran, R. Incorporating local water quality in welfare measures of agri-environmental policy: A choice modelling approach employing GIS. In Proceedings of the European Association of Agricultural Economists 2011 Congress "Change and Uncertainty", Zurich, Switzerland, 30 Augest-2 Sepember 2011.

11. Ferrini, S.; Scarpa, R. Designs with a priori information for nonmarket valuation with choice experiments: A Monte Carlo study. J. Environ. Econ. Manag. 2007, 53, 342-363.

12. Lancsar, E.; Louviere, J. Estimating Individual Level Discrete Choice Models and Welfare Measures Using Best-Worst Choice Experiments and Sequential Best-Worst MNL; University of Technology, Centre for the Study of Choice (Censoc): Sydney, Australia, 2008.

13. Louviere, J.J. Complex Statistical Choice Models: Are the Assumptions True, and if Not, What Are the Consequences; Oxford University: Oxford, UK, 2004.

14. Louviere, J.J.; Street, D.; Burgess, L.; Wasi, N.; Islam, T.; Marley, A.A.J. Modeling the choices of individual decision-makers by combining efficient choice experiment designs with extra preference information. J. Choice Model. 2008, 1, 128-163.

15. Marsh, D.; Phillips, Y. Difficult choices: What influences the error variance in a choice experiment. In Proceedings of the 2012 NZARES Conference, Nelson, New Zealand, 30-31 August 2012.

16. Transport and Mobility Laboratory: Biogeme. Available online: http://biogeme.epfl.ch/ (accessed on 14 April 2015).

17. Ben-Akiva, M.; Morikawa, T.; Shiroishi, F. Analysis of the Reliability of Preference Ranking Data. J. Bus. Res. 1992, 24, 149-164.

18. Bradley, M.; Daly, A. Use of the logit scaling approach to test for rank-order and fatigue effects in stated preference data. Transportation 1994, 21, 167.

19. Deshazo, J.R.; Fermo, G. Designing choice sets for stated preference methods: The effect of complexity on choice consistency. J. Environ. Econ. Manag. 2002, 44, 123-143.

20. Hess, S.; Rose, J.M.; Hensher, D.A. Asymmetric preference formation in willingness to pay estimates in discrete choice models. Transp. Res. 2008, 44, 847-863.

21. Lanz, B.; Provins, A.; Bateman, I.J.; Scarpa, R.; Willis, K.; Ozdemiroglu, E. Invistigating willingness to pay-willingness to accept asymmetry in choice experiments. In Choice Modelling the State-of-the-Art and the State-of-Practice; Hess, S., Daly, A., Eds.; Emerald Group Publishing Limited: Wagon Lane, UK, 2010; pp. 517-541.

22. Kahneman, D.; Knetsch, J.L.; Thaler, R.H. Anomalies: The endownment effect, loss aversion and status quo bias. J. Econ. Perspect. 1991, 5, 193-206.

23. Hess, S.; Axhausen, K.W. Distributional Assumptions. In Proceedings of the 5th Swiss Transport Research Conference, Ascona, Switzerland, 9-11 March 2005.

24. Scarpa, R.; Gilbride, T.J.; Campbell, D.; Hensher, D.A. Modelling attribute non-attendance in choice experiments for rural landscape valuation. Eur. Rev. Agric. Econ. 2009, 36, 151-174. 
25. National Policy Statment for Freshwater Management. Available online: http://www.mfe.govt.nz/ publications/fresh-water/national-policy-statement-freshwater-management-2014 (accessed on 14 April 2015).

26. Hurunui and Waiau River Regional Plan. Available online: http://ecan.govt.nz/publications/ Plans/hurunui-waiau-regional-plan.pdf (accessed on 14 April 2015).

27. Willig, R. Consumer's surplus without apology. Am. Econ. Rev. 1976, 66, 589-597.

28. Rowe, R.D.; d'Arge, R.C.; Brookshire, D.S. An experiment on the economic value of visibility. J. Environ. Econ. Manag. 1980, 7, 1-19.

29. Hanemann, W.M. Willingness to pay and willingness to accept: How much can they differ? Am. Econ. Rev. 1991, 81, 635-647.

30. Anderson, J.; Vadnjal, D.; Uhlin, H. Moral dimensions of the WTA-WTP disparity: An experimental examination. Ecol. Econ. 2000, 32, 53-162

31. Horowitz, J.K.; McConnell, K.E. A Review of WTA/WTP Studies. J. Environ. Econ. Manag. 2002, 44, 426-447.

32. Marsh, D. Water resource management in New Zealand: Jobs or algal blooms? J. Environ. Manag. 2012, 109, 33-42.

33. Effects of Scenarios on Environmental Values. Available online: http://ecan.govt.nz/publications/ General/luwq-catchment-workshop-3-norton-kelly-271010.pdf (accessed on 14 April 2015).

(C) 2015 by the authors; licensee MDPI, Basel, Switzerland. This article is an open access article distributed under the terms and conditions of the Creative Commons Attribution license (http://creativecommons.org/licenses/by/4.0/). 